\title{
VALUE OF ISCHEMIA MODIFIED ALBUMIN (IMA) FOR DIAGNOSIS OF ACUTE CORONARY SYNDROME (ACS) IN PATIENTS WITH ACUTE CHEST PAIN
}

\section{AUTHORS}

Dragojević I. ${ }^{1}$, Kisić B. ${ }^{1}$, Mirić M. ${ }^{2}$, Puhalo Sladoje D. ${ }^{3}$

${ }^{1}$ Institute of Biochemistry, Medical Faculty Pristina, Kosovska Mitrovica, Serbia

${ }^{2}$ Institute of Physiology, Medical Faculty Pristina, Kosovska Mitrovica, Serbia

${ }^{3}$ Medical Faculty, University of East Sarajevo, Serbian Republic, Bosnia and Herzegovina

\section{KORESPONDENT}

ILIJA DRAGOJEVIĆ

Institute of Biochemistry, Medical Faculty Pristina, Kosovska Mitrovica, Serbia

$\square$ ilija_dr@yahoo.com

\section{SUMMARY}

The aim of this study was to evaluate the diagnostic accuracy of ischemia modified albumin (IMA) alone, or in combination with cardiac troponin T (cTnT) and electrocardiogram (ECG) findings for diagnosis of acute coronary syndrome (ACS). The study included patients with acute chest pain suggestive on ACS, recruited within 6 hours from onset. Patients were classified in ACS group and non-ischemic chest pain group (NICP). Of 84 patients, 49 were diagnosed with ACS and 35 with NICP. IMA was significantly higher in ACS group $(p<0.0001)$. The area under receiver operating curve for IMA in ACS diagnosis was $0.95(p<0.0001)$. Sensitivity and specificity of IMA for ACS diagnosis were $89.8 \%$ and $91.4 \%$, respectively. IMA significantly $(\mathrm{p}<0.05)$ improved the sensitivity of ECG and $c T n T$, alone, and in combination. Sensitivity and negative predictive value of combination of IMA, ECG and CTnT for diagnosis of ACS were $100 \%$. IMA is useful for diagnosis of ACS, in combination with ECG and CTnT.

Keywords: ischemia modified albumin; acute coronary syndrome; sensitivity; negative predictive value.

\section{INTRODUCTION}

The diagnosis of acute coronary syndrome (ACS) is currently based on evaluation of symptoms, electrocardiographic (ECG) findings and determination of markers of myocardial necrosis. An ACS may occasionally occur in the absence of ECG changes or elevations of biochemical markers, when the diagnosis is supported by the presence of previously documented coronary artery disease or subsequent confirmatory investigations [1]. ACS encompasses a wide spectrum of pathological conditions, ranging from unstable angina (UA) to transmural acute myocardial infarction (AMI). Although these are different clinical presentations of ACS they usually share a common pathophysiological substrate. In most conditions, the basic pathophysiological mechanisms of ACS include atherosclerotic plaque rupture or erosion, with differing degrees of superimposed thrombosis and distal embolization, resulting in myocardial hypoperfusion [2].

Markers of myocardial necrosis have particular kinetics, thus can be detected in the blood 4-6 hours after insult. However, they can poorly discriminate UA from AMI patients. ECG changes are present at admission in about $50 \%$ of patients with ACS, and although widely used neither ECG findings nor determination of markers of myocardial necrosis can serve as a standard for the diagnosis of AMI. There is a constant need to establish early and sensitive markers of cardiac ischemia that will be able either alone or in combination with existing di- agnostic tools to identify patients with ACS. Such marker could serve for initial identification of patients with ACS, followed by subsequent confirmation of the diagnosis of AMI versus UA using a sensitive and specific test for the presence of myocardial necrosis.

Albumin, with $\mathrm{N}$-terminal part damaged or occupied with copper is referred to as ischemia modified albumin (IMA). One of the prominent features of IMA is inability to bind transition metal ions, such as cobalt. Bar-Or first reported a reduced binding of divalent cobalt ion added in vitro to human serum albumin in patients with ACS. On that basis, the test was developed in a prototype form, originally known as "assay for cobalt-albumin binding". Upon addition of cobalt solution to the serum, its attachment to albumin is measured using a colorimetric indicator dithiothreitol (DTT). In healthy individuals, the test was associated with less cobalt left to react with DTT. In patients with myocardial ischemia cobalt is not adhering to the $\mathrm{N}$-terminal part of albumin, and more free cobalt is available to react with DTT [3].

\section{STUDY OBJECTIVE}

The aim of this study was to evaluate the diagnostic accuracy of IMA, alone and in combination with cardiac troponin T (cTnT) and ECG in patients presenting within the first 6 hours from the onset of acute chest pain suggestive for ACS. 


\section{MATHERIAL AND METHODS}

\section{SUBJECTS}

Patients admitted to the Coronary Care Unit, Medical Center, Kosovska Mitrovica, within 6 hours from the onset of acute chest pain suggestive of ACS were prospectively included in the study. Exclusion criteria were acute renal failure, peripheral vascular disease, congenital heart disease, autoimmune diseases, acute mesenteric ischemia, primary cardiomyopathy, brain ischemia, acute infection and albumin concentration outside of reference interval. All patients provided informed consent before participating in the study. This research was conducted following the tenets of the Declaration of Helsinki and approved by the institutional review board of Medical Faculty Pristina (Kosovska Mitrovica).

The diagnosis of ACS was based on the Joint European Society of Cardiology/American College of Cardiology Committee (ESC/ACC) guidelines [2, 4 - 6]. The ACS group was consisted of patients with persistent ST-segment elevation (STEMI), non ST-segment myocardial infarction (NSTEMI) and UA. The NSTEMI was defined as significant ST-segment depression and T-wave abnormalities and elevated cTnT. The UA was defined as normal cTnT but with significant ST-segment and T-wave abnormalities. This subgroup also included patients with normal or undetermined ECG and normal CTnT, whose clinical presentation was suggestive for myocardial ischemia, supported by previously diagnosed coronary artery disease or subsequent confirmatory investigations. The control group was consisted of patients with non-ischemic chest pain (NICP) in whom myocardial ischemia was finally excluded as the cause of symptoms.

\section{Biochemical methods}

The blood was collected at admission into the test tube without anticoagulant, and spun at $3000 \mathrm{rpm}$ for 15 min to obtain serum for routine biochemical analyzes, including $\mathrm{CTnT}$.

\section{Measurement of IMA concentration}

For determination of IMA we employed the method of Bar-Or, as described [3]. In brief, $200 \mu \mathrm{L}$ of serum was gently mixed with $50 \mu \mathrm{L}$ of cobalt chloride (Sigma, 7.7 $\mathrm{mmol} / \mathrm{L} \mathrm{CoCl} 2 \times 6 \mathrm{H} 20)$. After 10 minutes incubation at room temperature $50 \mu \mathrm{L}$ of DTT (Sigma, $9.7 \mathrm{mM} / \mathrm{L}$ ) was added, and after exactly 2 minutes the reaction was quenched by addition of $1.0 \mathrm{~mL}$ physiological saline solution. The intensity of maroon color was measured on UV/VIS spectrophotometer (Safas 2, Monaco) at $\lambda=470$ $\mathrm{nm}$ against the sample blank in which cobalt solution was replaced with water. The results were reported in absorbance units (ABSU). The linearity of IMA assay was tested using commercial human serum albumin in a concentration range of 20.7-62.0 g/L. Within-run CV was assessed by analyzing ten replicates of a pooled human serum with $A B S U$ close to optimal cut-off determined by ROC curve analyses. The same sample was also used for the between-day CV estimation over five consecutive days.

\section{Other biochemical measurements}

Serum cTnT was determined by electrochemiluminescence immunoassay on Roche Elecsys 2010, using Troponin T STAT third generation test (Roche Diagnostics, Mannheim, Germany). Concentration of $\mathrm{cTnT}>0.03 \mu \mathrm{g} / \mathrm{L}$ was adopted as manufacturer's recommended criterion for diagnosis of myocardial infarction (MI). Serum albumin, glucose and lipid status were assessed on automatic analyzer Hitachi 902 (Roche Diagnostics, Mannheim, Germany) .

\section{Statistical methods}

All data were analyzed using MedCalc 12.3.0.0 (MedCalc Software, Belgium). Data distribution and homogeneity of variance were tested by the KolmogorovSmirnov test. Continuous variables with normal distribution were presented as mean and standard deviation, or median and 95\% confidence interval $(\mathrm{Cl})$ for median. Differences between groups were tested by Student's t-test or Mann-Whitney test, where appropriate.

The receiver operating characteristic (ROC) curve was generated to evaluate the ability of IMA in diagnosis of ACS. We determined optimal cut-off value for IMA, as combination of the smallest number of false positive and false negative results. The optimal cut-off was in the same time the criterion value for maximal Youden index. Also, bootstrapped $95 \% \mathrm{Cl}$ was calculated for both the Youden index and corresponding criterion value.

The area under ROC curve (AUC) was calculated with 95\% CI. IMA, CTnT and ischemic ECG changes were analyzed to determine sensitivity, specificity, positive and negative predictive value and likelihood ratio for diagnosis of ACS. A McNemar's test was used to compare the sensitivity and specificity of individual variables and their combinations for diagnosis of ACS. The combination was positive when one or more variables were positive. The combination was considered negative when all variables were negative. The following findings were considered positive: $C T n T>0.03 \mathrm{ng} / \mathrm{mL}$, IMA $>$ cut-off value (calculated from ROC curve), ECG changes suggestive for myocardial ischemia- significant ST-segment elevation and depression, T-wave inversion in at least two contiguous leads. In all other cases variables were regarded as negative. Correlation analysis was accomplished by calculation of Spearman's rank correlation coefficient. Linear regression was used to determine the linearity of IMA assay. Statistical significance was set at $p<0.05$.

\section{RESULTS}

The recruitment of patients in the study is reported in Figure 1. Of 114 eligible patients, 30 were excluded due to objective problems. Of remaining 84 patients, 49 were with final diagnosis of ACS (29 AMI, $20 \mathrm{UA})$ and 35 with NICP. In the UA group, a clinical diagnosis was established in 4 cases while in 16 cases the diagnosis was based on objective testing (dobutamine stress echocardiogram or exercise stress test).

Basic demographical and clinical characteristics of studied patients are presented in Table 1 . There were no significant differences between groups in sex, cigarette smoking, diabetes mellitus and lipid status. Patients in ACS group were older than those in NICP group. Previous $\mathrm{MI}$ was more common in ACS than in NICP group. 
Figure 1. STARD flow diagram presenting the recruitment of participants in the study

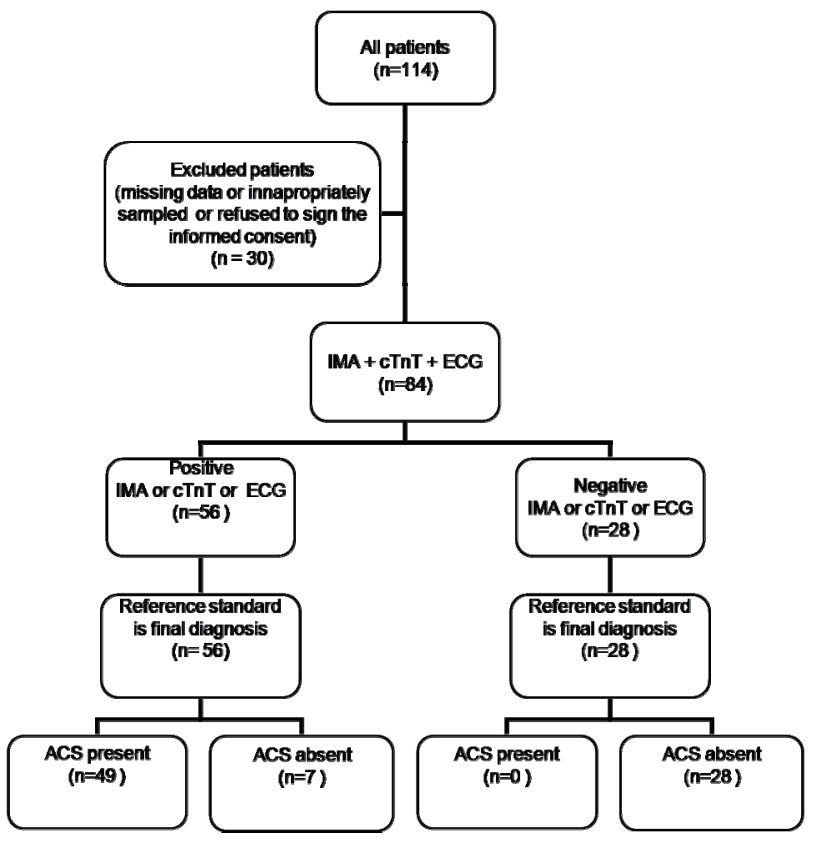

Figure 2. Receiver operating characteristic (ROC) curve of IMA absorbance units (ABSU) was derived for acute coronary syndrome versus nonischemic chest pain patients. Optimal cut-off value (in ABSU) is indicated

IMA

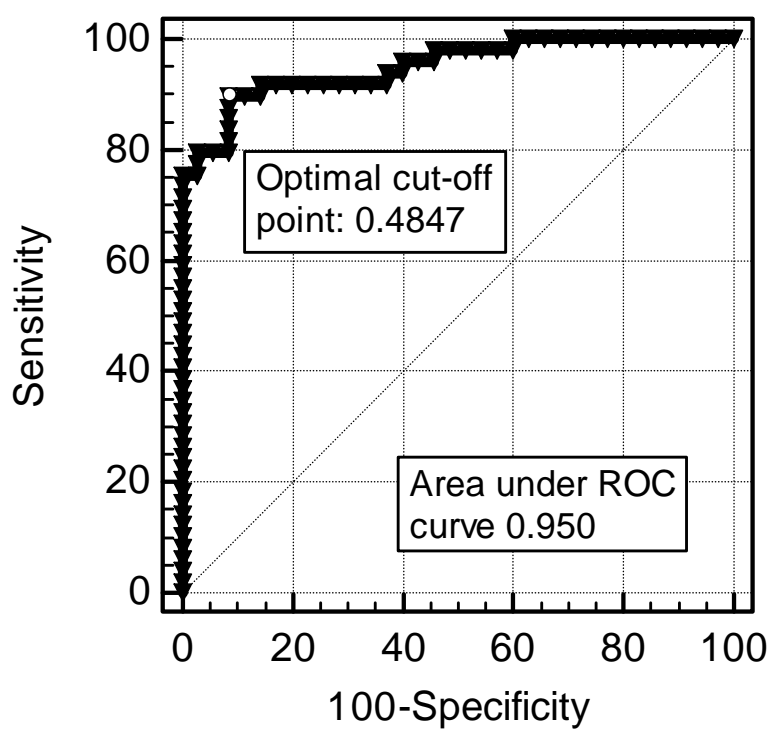

In comparison to NICP group, the median serum IMA was significantly higher in ACS group $(p<0.0001)$. Also, in AMI subgroup serum IMA was 0.762 ABSU $(95 \% \mathrm{Cl} 0.687$ $0.913)$ and $0.674 \mathrm{ABSU}(95 \% \mathrm{Cl} 0.534-0.695)$ in the NAP subgroup, and the difference was significant $(p=0.033)$.

The ROC curve analysis of IMA in ACS versus NICP (Figure 2) revealed an area of $0.95(95 \% \mathrm{Cl}, 0.879-0.986)$, that was highly significant $(\mathrm{p}<0.0001)$. Optimal cut-off value determined from ROC curve was $0.4847 \mathrm{ABSU}$. At that point the Youden index was $0.8122(95 \% \mathrm{Cl}, 0.673$ 0.902 ). At a cut-off point of $0.4847 \mathrm{ABSU}$ sensitivity and specificity were $89.8 \%(95 \% \mathrm{Cl}, 77.8-96.6)$ and $91.43 \%$ (76.9-98.2), respectively (Table 2 ). The positive predic- tive value was $93.62 \%$, and the negative predictive value was $86.49 \%$.

IMA showed good linearity in the range of albumin concentrations 20.7-62.0 g/L. The regression equation was as follows: IMA (ABSU) $=0.9875-0.0122 \times$ albumin $(\mathrm{g} / \mathrm{L})$. The within-run CV was $4.1 \%$ at a mean IMA of 0.4954 . The between-day CV was $3.6 \%$ at a mean IMA of 0.4864 . The mean IMA was close to optimal cut-off value.

The diagnostic accuracy of IMA, ECG and CTnT, used alone and in combination, for diagnosis of ACS is presented in Table 2. In comparison to ECG, CTnT, alone or in combination, the sensitivity of IMA for diagnosis of ACS was significantly higher $(p<0.05)$. The addition of IMA significantly $(p<0.05)$ improved the sensitivity of ECG and CTnT, alone and in combination. When IMA was combined both with ECG and CTnT the sensitivity and negative predictive value for the diagnosis of ACS reached maximal $100 \%$.

The concentration of albumin was significantly lower $(p<0.0001)$ in ACS group $(45.2 \pm 4.9 \mathrm{~g} / \mathrm{L})$ compared to NICP $(49.8 \pm 7.9 \mathrm{~g} / \mathrm{L})$. All measured concentrations of albumin were within normal range. Correlations between albumin and IMA (rho=0.05, p=0.71), IMA and cTnT (rho=0.2, p=0.17), and albumin and cTnT(rho $=-0.07$, $\mathrm{p}=0.63$ ) were not significant.

\section{DISCUSSION}

Despite of improvements in cardiac biomarkers and introduction of different diagnostic tools, the diagnosis of ACS still remains a significant challenge [5, 6]. For many reasons previously established diagnostic tools failed to recognize all ACS patients, as was also confirmed in our study. For example, ECG was shown to have low sensitivity (Table 2), while cTnT is by definition elevated in AMI. Thus, there is a constant need for new and more reliable cardiac biomarkers, of which IMA seems to be the most promising one.

Mechanisms involved in ischemia-induced changes of albumin molecule could be associated with exposure to endothelial and extracellular hypoxia, free radical damage, membrane energy-dependent sodium and calcium pump disruption, and free iron and copper ion exposure [7 - 9]. Conditions implicated in alteration of metal binding site of human serum albumin are known to occur in vivo within a few minutes after the onset of myocardial ischemia $[9,10]$, as was previously confirmed in patients undergoing percutaneous coronary interventions $[11,12]$. The study of Bar-Or et al. has also shown that acetylation or deletion of one or more amino acids on the $\mathrm{N}$-terminal tripeptide region results in the loss of albumin cobalt binding capacity [11].

In the current study we tested the ability of IMA to distinguish patients with ACS. In agreement with other studies $[3,11,13]$ we have found a significant elevation of IMA values in ACS compared to NICP group. Furthermore, IMA was significantly higher in the subgroup of AMI than in UA, suggesting that IMA actually reflects the extent of myocardial ischemia. However, there was no significant correlation between IMA and $\mathrm{CTnT}$, probably due to different marker kinetics during the development of ACS [11, 12]. On the other side, Sinha et al. reported higher IMA in UA than in AMI group [14].

We determined the optimal cut-off value of IMA for diagnosis of ACS from the ROC curve. Although this ap- 
Table 1. Basic demographic and clinical characteristics of patients

\begin{tabular}{|c|c|c|c|}
\hline Characteristics & $\operatorname{ACS}(\mathrm{N}=49)$ & NICP $(\mathrm{N}=35)$ & $\mathbf{P}$ \\
\hline Age (years) & $65 \pm 10$ & $48 \pm 11$ & $<0.0001$ \\
\hline Mále (\%) & $53 \%$ & $54 \%$ & 0.643 \\
\hline Smoking (\%) & $24.5 \%$ & $20 \%$ & $0.82 \overline{5}$ \\
\hline Hypertension (\%) & $81.6 \%$ & $68.6 \%$ & $0 . \overline{2} 6 \overline{3}$ \\
\hline Diabetes mellitus (\%) & $32.6 \%$ & $17.1 \%$ & 0.179 \\
\hline Hyperlipidaemia (\%) & $34.7 \%$ & $31.4 \%$ & $0,93 \overline{5}$ \\
\hline Previous MI (\%) & $26.5 \%$ & $5.7 \%$ & 0.03 \\
\hline IMA (ABSU) & $0.696(0.676-0.787)$ & $0.395(0.349-0.434)$ & $<0.0001$ \\
\hline
\end{tabular}

Data in acute coronary syndrome (ACS) and non-ischemic chast pain (NICP) groups are presented as mean value \pm SD, median and $95 \%$ confidence interval (in parenthesis), or frequency (\%). Differences between groups were calculated using t-test, MannWhitney U-test, or chi-square test, where appropriate.

Table 2. Diagnostic accuracy of several biomarkers in diagnosis of acute coronary syndrome

\begin{tabular}{|c|c|c|c|c|c|c|c|}
\hline & IMA & ECG & cTnT & $\begin{array}{c}\text { ECG } \\
+ \text { cTnT }\end{array}$ & $\begin{array}{l}\text { IMA } \\
+ \text { +ECG }\end{array}$ & $\begin{array}{c}\text { IMA } \\
+ \text { +CTnT } \\
\end{array}$ & $\begin{array}{c}\mathrm{MA}+\mathrm{ECG} \\
+\mathrm{cTnT}\end{array}$ \\
\hline Sensitivity & $\begin{array}{c}89.8 \\
(77.8-96.6)^{*}\end{array}$ & $\begin{array}{c}53.0 \\
(38.3-67.5)\end{array}$ & $\begin{array}{c}32.65 \\
(19.9-47.5)\end{array}$ & $\begin{array}{c}67.35 \\
(52.5-80.1) \\
\end{array}$ & $\begin{array}{c}97.96 \\
(92.7-100)^{*}\end{array}$ & $\begin{array}{c}93.8 \\
(83.1-98.7)^{*}\end{array}$ & $\begin{array}{c}100.0 \\
(92.7-100)^{*}\end{array}$ \\
\hline Specificity & $\begin{array}{c}91.4 \\
(76.9-98.2)\end{array}$ & $\begin{array}{c}91.43 \\
(76.9-98.2)\end{array}$ & $\begin{array}{c}100 \\
(90-100)\end{array}$ & $\begin{array}{c}91.43 \\
(76.9-98.2)\end{array}$ & $\begin{array}{c}80 \\
(63.1-91.6)\end{array}$ & $\begin{array}{c}88.57 \\
(73.3-96.8)\end{array}$ & $\begin{array}{c}80.0 \\
(63.1-91.5)\end{array}$ \\
\hline Positive PV & $\begin{array}{c}93.6 \\
(82.4-98.6)\end{array}$ & $\begin{array}{c}89.7 \\
(72.6-97.8)\end{array}$ & $\begin{array}{c}100 \\
(79.4-100)\end{array}$ & $\begin{array}{c}91.7 \\
(77.5-98.2)\end{array}$ & $\begin{array}{c}87.3 \\
(75.4-94.8)\end{array}$ & $\begin{array}{c}92 \\
(80.8-97.8)\end{array}$ & $\begin{array}{c}87.5 \\
(75.9-94.8)\end{array}$ \\
\hline Negative PV & $\begin{array}{r}86.4 \\
(71.2-95.4) \\
\end{array}$ & $\begin{array}{r}58.2 \\
(44-71.5) \\
\end{array}$ & $\begin{array}{r}51.5 \\
(39-63.8)\end{array}$ & $\begin{array}{r}66.7 \\
(51.6-79.6)\end{array}$ & $\begin{array}{r}96.6 \\
(82.2-99.9)\end{array}$ & $\begin{array}{c}91.2 \\
(76.0-98.2)\end{array}$ & $\begin{array}{r}100 \\
(87.6-100)\end{array}$ \\
\hline Positive LR & $\begin{array}{c}10.4 \\
(3.5-31.0)\end{array}$ & $\begin{array}{c}6.19 \\
(2.0-18.9)\end{array}$ & & $\begin{array}{l}7.86 \\
(2.6-23.6)\end{array}$ & $\begin{array}{c}4.9 \\
(2.5-9.5)\end{array}$ & $\begin{array}{l}8.21 \\
(3.3-20.7)\end{array}$ & $\begin{array}{c}5 \\
(2.58-9.7)\end{array}$ \\
\hline Negative LR & $\begin{array}{c}0.11 \\
(0.05-0.2)\end{array}$ & $\begin{array}{c}0.51 \\
(0.4-0.7)\end{array}$ & $\begin{array}{c}0.67^{\prime} \\
(0.6-0.8)\end{array}$ & $\begin{array}{c}0.36 \\
(0.2-0.5)\end{array}$ & $\begin{array}{c}0.026 \\
(0.004-0.2)\end{array}$ & $\begin{array}{c}0.069^{-} \\
(0.02-0.2)\end{array}$ & 0 \\
\hline
\end{tabular}

Specificity, sensitivity, predicted value (PV), and likelihood ratio (LR) were calculated in 84 patients for diagnostic accuracy of ischemia modified albumin (IMA), electrocariographical finding (ECG) and cardiac troponin T (CTnT) alone, or in combination, in diagnosing acute coronary syndrome. Data are presented as percentage and $95 \%$ confidence interval (in parenthesis). ${ }^{*} \mathrm{p}<0.05$ in comparison to ECG, $\mathrm{cTnT}$, alone and in combination.

proach is in discordance to established criteria for markers of myocardial necrosis [5], it is often applied in the studies of IMA. In healthy population the use of 99th percentile value of IMA as cut-off point could be associated with increased sensitivity but low specificity [15 17]. However, our results suggest that high sensitivity of IMA test found in this study may accurately discriminate whether patients presenting with acute chest pain do have ACS and therefore require hospitalization and adequate treatment. In personalized patient evaluation, biomarker sensitivity may be of crucial importance. In the current study serum IMA expressed high sensitivity of $89.8 \%$ and specificity of $91.4 \%$, which is in agreement with some other studies [18 - 20], although lower sensitivity and specificity was also reported [14, 17]. Moreover, the finding of low within-run and between-day variations indicate analytical reliability of IMA test. Despite of that, IMA alone failed to identify all patients with ACS in this (Table 2) and some previous studies.

We have also shown that sensitivity of IMA for ACS diagnosis can be significantly improved by combination with ECG and CTnT results. It has to be noted that this additive effect on IMA test accuracy was unrecognized in previous studies $[14,16,17]$. We have shown that IMA can significantly increase the sensitivity of ECG, CTnT and their combination, resulting in identification of virtually patients with ACS. And vice versa, it may be assumed that the diagnosis of ACS could be rejected with $100 \%$ certainty on the basis of normal IMA, normal cTnT, and normal ECG findings. Beyond clinical this finding may also have economic implications, because the correct ex- clusion of ACS would preserve expensive and limited resources of intensive care.

Other than relatively small sample size this study is limited for several reasons. One of the major sources of bias is absence of precise data for the time elapsed from the onset of symptoms to admission to the hospital. As described, we included all patients who endured acute chest pain for to up to 6 hours before admission. In other reports this period varied from 3 - 12 hours, and given that each biomarker has specific kinetics, it is hard to make comparisons. Another limitation is the lack of subsequent samples for IMA measurement, which would allow assessment of diagnostic accuracy of IMA in different time points from the onset of event. Furthermore, IMA is barely specific marker of myocardial ischemia, and altered cobalt binding to albumin can occur following strenuous exercise, as well as cerebral and intestinal ischemia $[21,22]$. Although patients with these conditions were excluded from the study, the results of IMA should be carefully interpreted, even in combination with other diagnostic tools.

\section{CONCLUSION}

To conclude, our results indicate that the diagnostic performance of IMA to distinguish ACS from NICP can be enhanced by combination with ECG and CTnT findings. 


\section{REFERENCES}

1. GRACE investigators. Rationale and design of the GRACE (Global Registry of Acute CoronaryEvents) Project: a multinational registry of patients hospitalized with acute coronary syndromes. Am Heart J 2001; 141:190-9.

2. Hamm CW, Bassand JP, Agewall S, Bax J, Boersma E, Bueno H, et al. ESC Guidelines for the management of acute coronary syndromes in patients presenting without persistent ST-segment elevation: The Task Force for the management of acute coronary syndromes (ACS) in patients presenting without persistent ST-segment elevation of the European Society of Cardiology (ESC). Eur Heart J 2011; 32:2999-3054.

3. Bar-Or D, Lau E, Winkler JV. A novel assay for cobalt-albumin binding and its potential as a marker for myocardial ischemia. J Emerg Med 2000; 19:311-315.

4. Bertrand ME, Simoons ML, Fox KA, Wallentin LC, Hamm ChW, Mc Fadden E, et al. Management of acute coronary syndromes in patients presenting without persistent ST-segment elevation. Eur Heart J 2002; 23:1809-1840.

5. Steg PG, James SK, Atar D, Badano LP, Lundqvist CB, Borger MA, et al. ESC Guidelines for the management of acute myocardial infarction in patients presenting with ST-segment elevation: The Task Force on the management of ST-segment elevation acute myocardial infarction of the European Society of Cardiology (ESC). Eur Heart J 2012; 33:2569-2619.

6. Graham I, Atar D, Borch-Johnsen K, Boysen G, Burell G, Cifkova R, et al. European guidelines on cardiovascular disease prevention in clinical practice: full text. Fourth Joint Task Force of the European Society of Cardiology and other societies on cardiovascular disease prevention in clinical practice (constituted by representatives of nine societies and by invited experts). Eur $\mathrm{J}$ Cardiovasc Prev Rehabil 2007; Suppl 2:S1-113.

7. McCord JM. Oxygen-derived free radicals in postischemic tissue injury. N Engl J Med 1985;312:159-63.

8. Cobbe SM, Poole-Wilson PA. The time of onset and severity of acidosis in myocardial ischemia. J Mol Cell Biol 1980; 12:745-60.

9. Berenshtein E, Mayer B, Goldberg C, Kitrossky N, Chevion M. Patterns of mobilization of copper and iron following myocardial ischemia: possible predictive criteria for tissue injury. J Mol Cell Cardiol 1997; 29:3025-4.

10. Reimer KA, Lowe JE, Rasmussen MM, Jennings RB. The wavefront phenomenon of ischemic cell death. 1. Myocardial infarct size vs. duration of coronary occlusion in dogs. Circulation 1977; 56:786-94.

11. Bar-Or D, Winkler JV, VanBenthuysen K, Harris L, Lau E, Hetzel FW. Reduced albumin-cobalt binding with transient myocardial ischemia after elective percutaneous transluminal coronary angioplasty: a preliminary comparison to creatine kinaseMB, myoglobin and troponin I. Am Heart J 2001;141:985-991.

12. Sinha MK, Gaze DC, Tippins JR, Collinson PO, Kaski JC. Ischemia modified albumin is a sensitive marker of myocardial ischemia after percutaneous coronary intervention. Circulation 2003; 107:2403-2405.

13. Garrido IP, Roy D, Calvino R, Vazquez-Rodriguez JM, Aldama G, Cosin-Sales J, et al. Comparison of ischemia-modified albumin levels in patients undergoing percutaneous coronary intervention for unstable angina pectoris with versus without coronary collaterals. Am J Cardiol 2004; 93:88-90.

14. Sinha MK, Roy D, Gaze DC, Kaski JC. Role of "Ischemia Modified Albumin", a new biochemical marker of myocardial ischemia, in the early diagnosis of acute coronary syndromes. Emerg Med J 2004; 21:29-34.

15. Roy D, Quiles J, Aldama G, Sinha M, Avanzas P, Arroyo-Espliguero R, et al. Ischemia modified albumin for the assessment of patients presenting to the emergency department with acute chest pain but normal or non-diagnostic 12-lead electrocardiograms and negative cardiac troponin T. Int J Cardiol 2004; 97:297-301.

16. Hjortshoj S, Kristensen SR, Ravkilde J. Diagnostic value of ischemia-modified albumin in patients with suspected acute coronary syndrome. Am J Emer Med 2010; 28:170-176.

17. Behera S, Mangaraj M, Mohapatra PCh. Diagnostic efficacy of ischemia modified albumin and its correlation with lipid profile, oxidative stress in acute myocardial infarct patients on admission. Asian Pacific Journal of Tropical Disease 2012; 62-65.

18. Liyan C, Jie Zh, Yonghua W, Xiaozhou H. Assay of ischemia-modified albumin and C-reactive protein for early diagnosis of acute coronary syndromes. J Clin Lab Anal 2008; 22:45-49.

19. Abadie JM, Blassingame CL, Bankson DD. Albumin cobalt binding assay to rule out acute coronary syndrome. Ann Clin Lab Sci 2005; 35:66-72.

20. Charpentier S, Ducasse JL, Cournot M, Maupas- Schwalm F, Elbaz M, Baixas C, et al. Clinical assessment of ischemia-modified albumin and heart fatty acid-binding protein in the early diagnosis of non-ST-elevation acute coronary syndrome in the emergency department. Acad Emerg Med 2010; 17:27-35.

21. Apple FS, Quist HE, Otto AP, Mathews WE, Murakami MM. Release characteristics of cardiac biomarkers and ischemia-modified albumin as measured by the albumin cobalt-binding test after a marathon race. Clin Chem 2002; 48:1097-100.

22. Senes M, Kazan N, Coskun O, Zengi O, Inan L, Yucel D. Oxidative and nitrosative stress in acute ischaemic stroke. Ann Clin Biochem 2007; 44:43-7. 


\section{SRPSKI}

\section{ZNAČAJ ISHEMIJOM MODIFIKOVANOG ALBUMINA (IMA) ZA DIJAGNOZU AKUTNOG KORONARNOG SINDROMA (AKS) KOD PACIJENATA SA AKUTNIM BOLOM U GRUDIMA}

Dragojević I. ${ }^{1}$, Kisić B. ${ }^{1}$, Mirić M. ${ }^{2}$, Puhalo Sladoje D. ${ }^{3}$.

${ }^{1}$ Institut za Biohemiju, Medicinski fakultet Priština, Kosovska Mitrovica, Srbija

2 Institut za Fiziologiju, Medicinski fakultet Priština, Kosovska Mitrovica, Srbija

${ }^{3}$ Medicinski fakultet, Univerzitet Istočno Sarajevo, Republika Srpska, Bosna i Hercegovina

\section{SAŽETAK}

Cilj istraživanja je bio procena vrednosti ishemijom modifikovanog albumina (IMA) zasebno, i u kombinaciji sa srčanim troponinom T (cTnT) i elektrokardiografskim nalazom (EKG), u dijagnozi akutnog koronarnog sindroma (AKS). Istraživanje je obuhvatilo pacijente sa akutnim bolom u grudima, suspektnim na AKS, od čije pojave do pregleda je proteklo manje od 6 sati. Pacijenti su klasifikovani u dve grupe, sa AKS i grupu sa bolom u grudima neishemijskog porekla. Istraživanje je obuhvatilo 84 pacijenta, 49 sa AKS i 35 sa bolom u grudima neishemijskog porekla. Vrednosti IMA su bile značajno veće u grupi sa AKS $(p<0.0001)$. Polje ispod ROC (receiver operating characteristic) krive je bilo 0.95 ( $p<0.0001$ ). Senzitivnost i specifičnost IMA u dijagnozi AKS je bila 89.8\% i 91.4\%. Kombinacija IMA sa EKG nalazom i koncentracijom cTnT, pojedinačno ili sa oba, je značajno povećala njihovu senzitivnost u dijagnozi AKS. Senzitivnosti i negativna prediktivna vrednost kombinacije IMA, EKG i cTnT u dijagnozi AKS je bila 100\%. Primena IMA u kombinaciji sa EKG nalazom i vrednošću cTnT se pokazala korisnom za dijagnozu AKS.

Ključne reči: ishemijom modifikovani albumin, akutni koronarni sindrom, senzitivnost, negativna prediktivna vrednost. 